\title{
THE ROLE OF BIOFERTILIZIERS IN THE AVAILABILITY OF POTASSIUM FOR POTATO CROP
}

\author{
Abo El-Khair, Amal W., A. A. A. Mohamed and \\ Azza A. M. Abd El-Aal \\ Soils, Water and Environ. Res. Inst. Agric. Res. Center (ARC), Giza, \\ Egypt
}

\begin{abstract}
A field experiment was conducted at EL- Kassassien Agric. Res. Station (ARC), EL- Ismaielia Governorate in the winter season of 2007 / 2008, to study the effect of inoculation with either Bacillus circulans (Silicate (potassium) dissolving bacteria or cyanobacteria (nitrogen fixers and plant growth promoters) on the availability of potassium from both potassium sulfate $\left(48 \% \mathrm{~K}_{2} \mathrm{O}\right)$ and feldspar $(10.5 \%$ $\mathrm{K}_{2} \mathrm{O}$ ) as a natural source of potassium to potato plants, as wall as, to investigate their effect on potato yield and its characters and soil available $\mathrm{N}, \mathrm{P}$ and $\mathrm{K}$ contents after potato harvesting and soil biological activities. Results indicated that inoculation with $B$. circulans and/or cyanobacteria (biofertilizers) in the presence of different potassium sources increased all examined potato tuber yield, tuber content of carbohydrate and soluble sugar, soil biological activity and soil available $\mathrm{N}, \mathrm{P}$ and $\mathrm{K}$ compared to the sole use of $\mathrm{K}$ - sources. The dual inoculation with bacteria and cyanobacteria in combination with both $\mathrm{K}$-sources at both tested levels surpassed all the tested treatments and gave the highest potato tuber yield with priority of K- sulfate source than K- feldspar source. However, the use of potassium (K-rock) minerals in combination with biofertilizers may be agronomically more useful and environmentally more feasible than soluble $\mathrm{K}$.
\end{abstract}

\section{INTRODUCTION}

Potassium is one of the three essential elements viz., NPK, for the growth and reproduction of the plants and it plays many vital roles in its nutrition. The crop production in Egypt relies completely on imports to meets its annual requirement of potash fertilizers besides; the high cost of conventional, water soluble $\mathrm{K}$ fertilizers constrains their use by most of the farmers in the country. In order to reduce the dependence on imported potash, feldspar natural potash mineral, contains from 10.50 to $11.25 \% \mathrm{~K}_{2} \mathrm{O}$ and therefore it could be a potential K-source for crop production. Novel approaches are needed to unlock $\mathrm{K}$ from the silicate structure of this mineral in order to render $\mathrm{K}$ more available for plant nutrition.

Potato (Solanum tuberosum L.) is one of the most important vegetable crops grown in Egypt. It needs potassium for its physiological processes. Potassium is essential for all living organisms. In plants, it is an important cation involved in physiological pathways (Steudle, 1994). Thus, efficient cell development and growth of plant tissues, translocation and storage of assimilates and other internal functions, which are based on many physiological, biochemical and biophysical interactions, require adequate $\mathrm{K}$ in the cell sap (Ruggiero et al., 1999). In the tropics, where water is a major limiting factor for successful crop production (Steudle and Peterson, 1998), 
Abo El-Khair, Amal W. et al.

potassium may tempe water stress due to its role in cell turgor control and metabolic activity (Abou-Arab et al., 1998). However, in most tropical soils K contents are low. The drastic raising in the chemical fertilizer prices especially potassium and their adverse effects on environment greatly incited the serious endeavors of many researchers to seek the relevant alternatives of synthetic fertilizers. These may be involving the extension in the practice of sustainable agriculture system, which relies mainly on the use of biofertilizers (Jensen and Hauggaard, 2003) in addition of utilizing the natural materials as sources of macro and micronutrients such as rock-phosphate, dolomite, feldspar, crushed lime stone and gypsum with efficient inoculants and organic materials (Conacher and Conacher, 1998; Abdel-Wahab et al., 2003 and Mekhemar et al., 2007). However, bio-fertilization is generally based on altering the rhizosphere flora, by either seed or soil inoculation with certain organisms, capable of inducing beneficial effects on a compatible host. However, biofertilizers mainly comprise nitrogen fixers, phosphate dissolvers and silicate bacteria (EL- Haddad, 1993). Numerous microorganisms, especially those associated with roots, have the ability to increase plant growth and productivity by many beneficial strategies comprised the solubilization of unavailable mineral nutrients (Kloepper et al., 1988). Cyanobacteria are known to produce a surface humus after death in soil, maintaining a reserve supply of elements such as $\mathrm{N}, \mathrm{P}$ and $\mathrm{K}$ for higher plants (Shields and Durrell, 1964). Beneficial effects of cyanobacteria as biofertilizer have been reported on a number of other crops rather than rice such as barley, oats, tomato, radish, cotton, sugarcane, maize, wheat, chili and lettuce (Thajuddin and Subramanian, 2005).

The aim of this work is to study the role of silicate bacteria (Bacillus circulans) and/or cyanobacteria inoculation both as a biofertilizer in releasing potassium from the natural source of potassium. As well as their effect on potato production, soil available NPK soil and soil biological activity.

\section{MATERIALS AND METHODS}

A field experiment was conducted at EL- Kassassien Agric. Res. Station (ARC), EL- Ismaielia Governorate in the winter season of 2007 / 2008, to study the effect of inoculation with either Bacillus circulans (Silicate (potassium) dissolving bacteria or cyanobacteria (nitrogen fixers and plant growth promoters) on the availability of potassium from both potassium sulfate $\left(48 \% \mathrm{~K}_{2} \mathrm{O}\right)$ and feldspar $\left(10.5 \% \mathrm{~K}_{2} \mathrm{O}\right)$ as a natural source of potassium to potato plants, as wall as, to investigate their effect on potato yield and its characters and soil available N, P and K contents after potato harvesting and soil biological activities.

\section{Plant materials:}

Certified seed potato tuber Nicola cultivar (locally produced and cold stored), obtained from the General Authority for producers and Exporters of Horticulture crops, Cairo, Egypt, was used in this experiment. Nicola cultivar is medium early to medium late. The whole seed tubers were cut to small pieces each containing 2-3 buds and planted, on 15th November, 2007. 


\section{Soil properties:}

Some physical and chemical analyses (Chapman and Pratt, 1961 and page et al., 1982) of the experimental soil are presented in Table (1).

Table (1): Some physical and chemical properties in of the experimental soil

\begin{tabular}{|c|c|c|c|c|c|c|c|c|}
\hline $\begin{array}{c}\text { Coarse } \\
\text { sand (\%) }\end{array}$ & $\begin{array}{l}\text { Fine } \\
\text { sand } \\
(\%)\end{array}$ & $\begin{array}{l}\text { Silt } \\
(\%)\end{array}$ & $\begin{array}{l}\text { Clay } \\
(\%)\end{array}$ & Sol & exture & \multicolumn{2}{|c|}{$\begin{array}{l}\text { OM } \\
(\%)\end{array}$} & $\begin{array}{c}\mathrm{CaCO}_{3} \\
(\%)\end{array}$ \\
\hline 3.10 & 70.77 & 20.00 & 6.23 & & $\begin{array}{l}\text { ndy } \\
\text { am }\end{array}$ & \multicolumn{2}{|c|}{0.45} & ---- \\
\hline \multirow{2}{*}{$\begin{array}{c}\mathrm{pH} \\
(1: 2: 5)\end{array}$} & \multirow{2}{*}{$\begin{array}{c}E C \\
(\mathrm{dS} / \mathrm{m})\end{array}$} & \multicolumn{2}{|c|}{ Cations } & \multicolumn{2}{|c|}{$(\mathrm{meq} / \mathrm{l})$} & \multicolumn{2}{|c|}{ Anions } & (meq/l) \\
\hline & & $\mathrm{Ca}^{++}$ & $\mathrm{Mg}^{++}$ & $\mathrm{Na}^{+}$ & $\mathrm{K}^{+}$ & $\mathrm{HCO}_{3}^{-}$ & $\mathrm{Cl}^{-}$ & $\mathrm{SO}_{4}^{-{ }_{4}}$ \\
\hline 8.40 & 0.38 & 0.33 & 0.54 & 0.98 & 0.06 & 0.43 & 0.54 & 1.25 \\
\hline \multicolumn{9}{|c|}{ Available Macro-nutrients $\left(\mathrm{mg} \mathrm{kg}^{-1}\right)$} \\
\hline \multicolumn{3}{|c|}{$\mathbf{N}$} & \multicolumn{3}{|c|}{$\mathbf{P}$} & \multicolumn{3}{|c|}{$\mathbf{K}$} \\
\hline \multicolumn{3}{|c|}{30} & \multicolumn{3}{|c|}{85} & \multicolumn{3}{|c|}{210} \\
\hline
\end{tabular}

\section{Bacteria used:}

Two kinds of bio fertilizers were used in this experiment. The first is Bacillus. circulans (silicate dissolver) and cyanobacteria (nitrogen fixers and growth promoters), both are kindly supplied with the Dept. Agric. Microbiol. Res., Soils, Water \& Environ. Res. Inst., ARC, Giza, Egypt. Inoculants preparation:

\section{a) Bacillus. Circulans inoculum:}

Vermiculite supplemented with $10 \%$ Irish peat was packed into polyethylene bags ( $200 \mathrm{~g}$ carrier per bag), then sealed and sterilized with gamma irradiation (5.0× $10^{6}$ rads). Bacillus circulans was grown on nutrient broth medium (Difico Manual, 1984) incubated for $48 \mathrm{hr}$ at $28^{\circ} \mathrm{C}$ to ensure population density of $5 \times 10^{9} \mathrm{cfu} / \mathrm{ml}$ culture and injected into sterilized carrier as mentioned before.

The efficiency of used strain of $B$. circulans for dissolving silicate minerals was assayed using powdered mica in the Aleksandrov's liquid medium (Zahara, 1969).

\section{B) Cyanobacteria inoculum:}

Slant agar refrigerated $\left(5^{\circ} \mathrm{C}\right)$ cyanobacteria strains were exposed to light (500 Lux) for 2 days then inoculated to liquid BG 11 (Rippika et al., 1979) medium to reach the exponential growth phase.. The developed cyanobacterial growth was homogenized and then introduced at the rate of $(1 \mathrm{ml})$ to $500 \mathrm{ml}$ conical flasks containing $100 \mathrm{ml}$ sterilized BG11 medium $(\mathrm{pH} 7.2)$ and incubated on continuous rotary shaking incubator (100 rpm) equipped with continuous illumination (3000 Lux) at temperature of 28 $32^{\circ} \mathrm{C}$. The cyanobacteria growth was then scaled up in 20 liters aspirator bottles or carboys. The mass cyanobacteria culture grown in these carboys will be ready to use as inoculum starter for soil based cyanobacteria inoculum (SBI) production in the field (Ghazal, 1987). The soil based cyanobacteria inoculum is composed of a mixture of nitrogen fixing cyanobacteria strains namely Anabaena variabilis, Nostoc sp, Aulosira fertilissima and Tolypothrix tenuis. 
Abo El-Khair, Amal W. et al.

The experiment was in split plot design in which the two sources (4 treatments) of potassium fertilizer represent the main plots and the bacterial inoculation (4 treatments) represents the sub plots. The experiment, then included 16 treatments in three replicates as the following:

Potassium treatments (main plots):

1- Full dose of $\mathrm{K}$ from potassium sulphate $\left(48 \% \mathrm{~K}_{2} \mathrm{O}\right)=200 \mathrm{~kg} \mathrm{fed}^{-1}$

2- $1 / 2$ Full dose of $\mathrm{K}$ from potassium sulphate. $=100 \mathrm{~kg} \mathrm{fed}^{-1}$.

3- Full dose of $\mathrm{K}$ from feldspar $\left(10.5 \% \mathrm{k}_{2} \mathrm{O}\right)=1000 \mathrm{~kg} \mathrm{fed}^{-1}$

4- $1 / 2$ Full dose of $\mathrm{K}$ from feldspar. $=500 \mathrm{~kg} \mathrm{fed}^{-1}$

Biofertilizer treatments (sub plots):

1- Bacillus circulans inoculum.

2- Cyanobacteria inoculation.

3- Cyanobacteria + Bacillus circulans

4- Without inoculation.

In plots that received Bacillus inoculation potato seeds was coated with the inoculum just before planting using a solution of $10 \%$ Arabic gum as adhesive agents. While, cyanobacteria inoculum was used twice in two forms, the first was added as an aqueous liquid cyanobacteria extract by dripping into the soil near the potato seeds, and the other form was added as dry inoculum (500 $\mathrm{g} \mathrm{fed}^{-1}$ ) by spreading on soil surface 10 days after germination. Each experimental plot contained 8 rows $(2 \mathrm{~m}$ length and $0.7 \mathrm{~m}$ width). Each plot received equivalent amount of $250 \mathrm{~kg} \mathrm{P}_{2} \mathrm{O}_{5} \mathrm{fed}^{-1}$ as superphosphate $15.5 \% \mathrm{P}_{2} \mathrm{O}_{5}$ before planting. Nitrogen was added in the form of ammonium nitrate $(33 \% \mathrm{~N})$ at the rate of $120 \mathrm{~kg} \mathrm{fed}^{-1}$ in four equal doses after $25,35,45$ and 55 days from planting. Feldspar $\left(10.5 \% \mathrm{~K}_{2} \mathrm{O}\right)$ was added to the plots once at planting in two rates of 500 and $1000 \mathrm{~kg} \mathrm{fed}^{-1}$ equivalent to 100 and $200 \mathrm{~kg}$ potassium sulfate $\left(48 \% \mathrm{~K}_{2} \mathrm{O}\right) \mathrm{fed}^{-1}$, which was added in two split dosed at planting and after 35 days from planting.

All the experimental plots received the same amount of water from planting till harvest through the normal submerged irrigation.

At harvest (120 days from planting), potato tubers were collected from the two middle ridges in each plot to determine total tuber yield (ton fed ${ }^{-1}$ ), total carbohydrate \% (A. O. A. C., 1990) and total soluble sugar (Dubbois, et al., 1956).

Potato rhizosphere soil was also sampled at 75 and 95 days from planting to determine the soil biological activity in terms of dehydrogenase activity (Casida et al., 1964), $\mathrm{CO}_{2}$ evolution (Pramer and Schmidt, 1964), total bacteria (Allen, 1959) total cyanobacteria (Allen and Stanier, 1968), Azotobacter and Azospirillum (Cochran, 1950). At harvest, soil samples were collected from each plot, air dried, pulverized, passed through $2 \mathrm{~mm}$ sieve and then subjected to determine the soil available $N, p$ and $K$ contents as described by Page et al. (1982).

All obtained results were statistically analyzed and compared to L. S. D. difference at probability level of 0.05 as described by Gomez and Gomez (1984). 


\section{RESULTS}

\section{Potato yield attributes:}

Data in Table (2) indicate the effect of inoculation with $B$. circulans and/or cyanobacteria (biofertilizers) in the presence of different potassium sources, i.e., potassium sulfate and feldspar on potato yield attributes. Results indicated that the use of biofertilizers in combination with $\mathrm{K}$ sources had positively enhanced all potato attributes compared to the use of both $\mathrm{K}$ sources each alone. This behavior was more obvious with potassium sulfate rather than feldspar.

Table (2): Potato yield attributes as affected with different potassium sources and levels and inoculation with silicate bacteria and/or cyanobacteria

\begin{tabular}{|c|c|c|c|c|c|}
\hline K Source & K level & Inoculation & $\begin{array}{l}\text { Number of } \\
\text { tuber plant }{ }^{-1}\end{array}$ & $\begin{array}{l}\text { Weight of } \\
\text { tuber plant }{ }^{-1} \\
\text { (g) }\end{array}$ & $\begin{array}{l}\text { Tuber yield } \\
\text { ton fed }^{-1}\end{array}$ \\
\hline \multirow{4}{*}{$\begin{array}{l}\text { Potassium } \\
\text { sulfate }\end{array}$} & \multirow{2}{*}{$\begin{array}{c}\text { 1/ } 2 \text { Full K } \\
\text { dose }\end{array}$} & Bacteria* & 9.33 & 320.87 & 10.90 \\
\hline & & Cyano.** & 7.50 & 300.20 & 08.33 \\
\hline & \multirow{2}{*}{ Full K dose } & Bacteria & 12.16 & 410.35 & 11.95 \\
\hline & & Cyano. & 8.17 & 365.83 & 12.61 \\
\hline \multirow{4}{*}{ Feldspar } & \multirow{2}{*}{$\begin{array}{l}\text { 1/ } 2 \text { Full K } \\
\text { dose }\end{array}$} & Bacteria & 8.12 & 375.12 & 11.65 \\
\hline & & Cyano. & 7.17 & 316.60 & 10.13 \\
\hline & \multirow{2}{*}{ Full K dose } & Bacteria & 9.00 & 372.00 & 12.24 \\
\hline & & Cyano. & 8.17 & 385.93 & 11.70 \\
\hline \multirow{2}{*}{$\begin{array}{l}\text { Potassium } \\
\text { sulfate }\end{array}$} & $\begin{array}{c}\text { 1/ } 2 \text { Full K } \\
\text { dose }\end{array}$ & \multirow{4}{*}{$\begin{array}{c}\text { Bacteria } \\
+ \\
\text { Cyano. }\end{array}$} & 12.52 & 530.92 & 14.20 \\
\hline & Full K dose & & 14.00 & 640.16 & 15.76 \\
\hline \multirow[t]{2}{*}{ Feldspar } & $\begin{array}{l}\text { 1/ } 2 \text { Full K } \\
\text { dose }\end{array}$ & & 11.10 & 415.20 & 13.31 \\
\hline & Full K dose & & 11.75 & 430.20 & 13.85 \\
\hline \multirow{2}{*}{$\begin{array}{l}\text { Potassium } \\
\text { sulfate }\end{array}$} & $\begin{array}{l}\text { 1/ } 2 \text { Full K } \\
\text { dose }\end{array}$ & \multirow{4}{*}{$\begin{array}{c}\text { Without } \\
\text { inoculation }\end{array}$} & 9.00 & 348.23 & 09.69 \\
\hline & Full K dose & & 12.67 & 490.10 & 12.82 \\
\hline \multirow{2}{*}{ Feldspar } & $\begin{array}{c}\text { 1/ } 2 \text { Full K } \\
\text { dose }\end{array}$ & & 5.17 & 309.17 & 05.33 \\
\hline & Full K dose & & 6.83 & 341.07 & 07.20 \\
\hline \multicolumn{3}{|l|}{ L. S. D. 0.05} & Ns. & Ns. & 1.32 \\
\hline
\end{tabular}

* Silicate bacteria - ** Cyanobacteria

The use of feldspar alone at half and full dose gave relatively the lowest number of tubers plant ${ }^{-1}$, weight of tubers plant ${ }^{-1}(\mathrm{~g})$ and tubers yield (tons $\mathrm{fed}^{-1}$ ). The corresponding values were 5.17 tubers plant $^{-1}, 309 \mathrm{~g} \mathrm{plant}^{-1}$ and 5.33 tons fed $^{-1}\left(1 / 2 \mathrm{~K}\right.$ dose from feldspar) and 6.83 tubers plant $^{-1}, 341.07$ g plant ${ }^{-1}$ and 7.20 tons fed $^{-1}$ (full $\mathrm{K}$ dose from feldspar). The use of full $\mathrm{K}$ dose either from feldspar or potassium sulfate had recorded higher potato yield attributes than the use of $1 / 2 \mathrm{~K}$ dose from feldspar and/or potassium sulfate. The inoculation with bacteria recorded better potato attributes than those recorded due to the inoculation with cyanobacteria. However, inoculation with potassium dissolving bacteria ( $B$. circulans) combined with full $\mathrm{K}$ from feldspar gave relatively similar potato tubers yield to that obtained due to the use of full $\mathrm{K}$ from potassium sulfate. The corresponding potato yields were 12.24 and 
12.82 tons fed $^{-1}$. On the other respect, the dual inoculation with $B$. circulans and cyanobacteria gave significantly the highest potato yield attributes compared to the inoculation with each alone. The highest potato yield of 15.76 tons fed $^{-1}$ was due to Full $\mathrm{K}$ dose from $\mathrm{K}_{2} \mathrm{SO}_{4}+$ Bacteria + Cyano. treatment followed 14.20 tons fed ${ }^{-1}$ (1/2 Full K dose from $\mathrm{K}_{2} \mathrm{SO}_{4}+$ Bacteria + Cyano) and 13.85 tons fed $^{-1}$ (Full K dose from feldspar + Bacteria + Cyano.).

\section{Total carbohydrate and total soluble sugar content of potato tubers:}

Data in Table (3) show total carbohydrate and total soluble sugars content of potato tubers in response to inoculation with $B$. circulans and/or cyanobacteria (biofertilizers) in the presence of different potassium sources. The dual inoculation with bacteria and cyanobacteria in combination with both $\mathrm{K}$ sources at both tested levels led to increase both potato carbohydrate and soluble sugars contents in comparison with those achieved due the other tested treatments. The highest total carbohydrate $(75.23 \%)$ and total soluble sugars $(4.36 \%)$ contents were due to Full $\mathrm{K}$ dose from $\mathrm{K}_{2} \mathrm{SO}_{4}+$ Bacteria + Cyano. treatment. The inoculation with cyanobacteria enhanced the carbohydrate and soluble sugar contents of potato tubers better than the inoculation with bacteria.

\section{Soil biological activity:}

Table (4) shows the effect of the tested treatments on potato plant rhizosphere soil biological activity, measured after $75 \& 95$ days from potato planting in terms of dehydrogenase activity (DHA), $\mathrm{CO}_{2}$ evolution, cyanobacteria count, bacteria count, Azotobacter count Pand Azospirillum count. Results indicated that all these parameters increased in both studied periods in respons to inoculation with either bacteria or cyanobacteria and/or both together, compared to the treatment without inoculation.

Nevertheless, increasing soil rhizosphere sampling period from 75 to 95 days decreased all the measured soil biological activity parameters mentioned in Table (4). The inoculation with either bacteria or cyanobacteria and/or both together in combination with both $\mathrm{K}$ sources at both levels led to increase (DHA), $\mathrm{CO}_{2}$ evolution, cyanobacteria count, bacteria count, Azotobacter count and Azospirillum count at 75 days over the treatments without inoculation. In this period, the highest DHA of $40.65 \mu \mathrm{g} \mathrm{TPF} \mathrm{g}{ }^{-1}$ dry soil was due to dual inoculation with bacteria and cyanobacteria + Full $\mathrm{K}$ dose from $\mathrm{K}_{2} \mathrm{SO}_{4}$. This treatment had achieved the highest value of $\mathrm{CO}_{2}$ evolution and the highest count of cyanobacteria, bacteria, Azotobacter and Azospirillum. The relative values were $166.85 \mathrm{mg} \mathrm{CO}_{2} 100 \mathrm{~g}^{-1}$ dry soil, $20 \mathrm{x}$ $10^{3} \mathrm{cfu}, 13 \times 10^{3} \mathrm{cfu}, 23 \times 10^{7} \mathrm{cfu}, 13.1510^{4} \mathrm{cfu}$ and $12.10 \times 10^{4} \mathrm{cfu}$. However, at 95 days, despite these parameters tended to decrease due to all the tested treatments, the dual inoculation with bacteria and cyanobacteria + Full $\mathrm{K}$ dose from $\mathrm{K}_{2} \mathrm{SO}_{4}$ still keeping the highest values for these biological tested parameters (Table 4). Owing to the potassium source and levels, markedly the use of potassium sulfate was slightly better than feldspar and the level of full $\mathrm{K}$ surpassed the level of half $\mathrm{K}$ in both $\mathrm{K}$ sources. Also, it is of worth to note that, both $\mathrm{DHA}$ and $\mathrm{CO}_{2}$ evolution increased in both tested period along with increasing the numbers of the counted microorganisms. As well as, generally, the use of biofertilizers $(B$. circulans and cyanobacteria 
and/or both together) had improved the biological activity of potato rhizosphere area when compared to un-inoculated treatments.

Table (3): Total carbohydrate content (\%) and total soluble sugar content (\%) in potato tubers as affected with different potassium sources and levels and inoculation with silicate bacteria and/or cyanobacteria

\begin{tabular}{|c|c|c|c|c|}
\hline Treatment & K - level & $\begin{array}{c}\text { Inoculation } \\
\text { type }\end{array}$ & Total carbohydrate (\%) & Total soluble sugar (\%)* \\
\hline \multirow{4}{*}{$\begin{array}{c}\text { Potassium } \\
\text { sulfate }\end{array}$} & \multirow{2}{*}{\begin{tabular}{|c|}
$\begin{array}{c}2 \text { Full K } \\
\text { dose }\end{array}$ \\
\end{tabular}} & Bacteria* & 51.21 & 2.80 \\
\hline & & Cyano.** & 58.39 & 3.40 \\
\hline & \multirow{2}{*}{ Full K dose } & Bacteria & 60.89 & 3.70 \\
\hline & & Cyano. & 61.67 & 3.90 \\
\hline \multirow{4}{*}{ Feldspar } & \multirow{2}{*}{$\begin{array}{c}1 / 2 \text { Full K } \\
\text { dose }\end{array}$} & bacteria & 46.22 & 2.70 \\
\hline & & Cyano. & 53.06 & 2.94 \\
\hline & \multirow{2}{*}{ Full K dose } & bacteria & 56.83 & 3.20 \\
\hline & & Cyano. & 62.33 & 3.65 \\
\hline \multirow{2}{*}{$\begin{array}{c}\text { Potassium } \\
\text { sulfate }\end{array}$} & $\begin{array}{c}1 / 2 \text { Full K } \\
\text { dose }\end{array}$ & \multirow{4}{*}{$\begin{array}{c}\text { Bacteria } \\
+ \\
\text { Cyano. }\end{array}$} & 70.20 & 4.30 \\
\hline & \begin{tabular}{|l|} 
Full K dose \\
\end{tabular} & & 75.23 & 4.36 \\
\hline \multirow[t]{2}{*}{ Feldspar } & $\begin{array}{c}1 / 2 \text { Full K } \\
\text { dose }\end{array}$ & & 63.31 & 4.21 \\
\hline & Full K dose & & 66.65 & 4.26 \\
\hline \multirow{2}{*}{$\begin{array}{c}\text { Potassium } \\
\text { sulfate }\end{array}$} & $\begin{array}{c}1 / 2 \text { Full K } \\
\text { dose }\end{array}$ & \multirow{4}{*}{$\begin{array}{c}\text { Without } \\
\text { inoculation }\end{array}$} & 49.72 & 2.35 \\
\hline & Full K dose & & 57.67 & 2.31 \\
\hline \multirow[t]{2}{*}{ Feldspar } & $\begin{array}{c}1 / 2 \text { Full K } \\
\text { dose }\end{array}$ & & 45.72 & 1.95 \\
\hline & Full K dose & & 51.73 & 2.11 \\
\hline
\end{tabular}

* Silicate bacteria - ** Cyanobacteria - *** On dry weight basis

\section{Soil N, P and $K$ availability:}

Table (5) shows the effect of the tested treatments on soil N, P \& K availability after potato harvesting. Results indicated that the application of biofertilizers combined with both $\mathrm{K}$ sources at both tested levels led to increase the soil N, P \& K availability after potato harvesting compared to either the initial soil before potato cultivation or the other treatments received no inoculation. However, inculcation with bacteria was superior in saving potassium in soil when applied with both $\mathrm{K}$ sources rather than cyanobacteria. The opposite trend for $\mathrm{N}$ and $\mathrm{p}$ was observed, since, cyanobacteria inoculation had successfully ensured more soil available $\mathrm{N}$ and $\mathrm{P}$ rather than bacteria inoculation. On the other hand, the dual inoculation with bacteria and cyanobacteria in combination with both tested $\mathrm{K}$ sources gave the highest soil available $\mathrm{N}, \mathrm{P}$ and $\mathrm{K}$ compared with the other tested treatment. However, the priority was also for K-sulfate source rather than Kfeldspar source when both accompanied with dual inoculation with both bacteria and cyanobacteria. 
Abo El-Khair, Amal W. et al.

$\mathrm{T} 4$

4322 
Table (5): Soil available N, P \& K after potato harvesting as affected with different potassium sources and levels and inoculation with silicate bacteria and/or cyanobacteria

\begin{tabular}{|c|c|c|c|c|c|}
\hline \multirow{2}{*}{ K Source } & \multirow{2}{*}{ K level } & \multirow{2}{*}{ Inoculation } & \multicolumn{3}{|c|}{ Soil available nutrients (mg kg soil ${ }^{-1}$ ) } \\
\hline & & & $\mathbf{N}$ & $\mathbf{P}$ & $\mathbf{K}$ \\
\hline \multirow{4}{*}{ Potassium sult } & \multirow{2}{*}{$\begin{array}{l}\text { 1/ } 2 \text { Full K } \\
\text { dose }\end{array}$} & Bacteria* $^{*}$ & 33.12 & 117.8 & 390.70 \\
\hline & & Cyano.** & 43.97 & 157.20 & 380.00 \\
\hline & \multirow{2}{*}{ Full K dose } & Bacteria & 54.23 & 162.00 & 563.35 \\
\hline & & Cyano. & 68.20 & 237.60 & 590.00 \\
\hline \multirow{4}{*}{ Feldspar } & \multirow{2}{*}{$\begin{array}{c}\text { 1/ } 2 \text { Full K } \\
\text { dose }\end{array}$} & Bacteria & 44.23 & 139.20 & 430.25 \\
\hline & & Cyano. & 49.00 & 156.0 & 466.35 \\
\hline & \multirow{2}{*}{ Full K dose } & Bacteria & 50.15 & 140.00 & 625.10 \\
\hline & & Cyano. & 52.59 & 216.40 & 457.70 \\
\hline \multirow[t]{2}{*}{ Potassium sult } & $\begin{array}{c}\text { 1/ } 2 \text { Full K } \\
\text { dose }\end{array}$ & \multirow{4}{*}{$\begin{array}{c}\text { Bacteria } \\
+ \\
\text { Cyano. }\end{array}$} & 66.20 & 260.75 & 490.65 \\
\hline & Full K dose & & 85.12 & 300.86 & 670.25 \\
\hline \multirow{2}{*}{ Feldspar } & $\begin{array}{c}\text { 1/ } 2 \text { Full K } \\
\text { dose }\end{array}$ & & 60.25 & 190.00 & 430.10 \\
\hline & Full K dose & & 68.40 & 219.75 & 490.00 \\
\hline \multirow[t]{2}{*}{ Potassium sult } & $\begin{array}{l}\text { 1/ } 2 \text { Full K } \\
\text { dose }\end{array}$ & \multirow{4}{*}{$\begin{array}{c}\text { Without } \\
\text { inoculation }\end{array}$} & 30.20 & 103.80 & 302.00 \\
\hline & Full K dose & & 35.80 & 116.80 & 282.10 \\
\hline \multirow[t]{2}{*}{ Feldspar } & $\begin{array}{l}\text { 1/ } 2 \text { Full K } \\
\text { dose }\end{array}$ & & 26.85 & 090.80 & 161.40 \\
\hline & Full K dose & & 38.94 & 102.75 & 219.10 \\
\hline
\end{tabular}

* Silicate bacteria - ** Cyanobacteria

\section{DISCUSSION}

Potato is considered one of the most important vegetable crops in Egypt. Increasing productivity of potato with good quality is an important target by the growers for local and foreign consumptions. Chemical potassium fertilizer became a high expensive fertilizer in Egypt, so most of farmers ignored using it. Thus, the use of alternative indigenous resources such as feldspar is gaining importance to alleviate the dependence of imported or costly commercial fertilizers. It is known that, potassium is one of the most important elements in the plant nutrition. It plays an important role on promotion of enzymes activity and enhancing the translocation of assimilates sugars, starch and protein synthesis. Moreover, it increases root growth, improve drought resistance, builds cellulose, reduces loading, control plant turgidity. Low levels of nutrients such as $\mathrm{K}$ is considered one of a major production constrains of all types of soil. Further more; potassium forms are the third most important plant nutrient limiting plant growth and consequently crop yield. Except nitrogen, potassium is a mineral nutrient that plants require in largest amount and assimilated in relatively large quantities by the growing crop as the yield and quality (Marschner, 1995). Potassium is absorbed by plants in larger amounts than any other mineral elements except nitrogen and phosphorus.

The main source of $\mathrm{K}$ for plants comes from $\mathrm{K}$ minerals and organic $\mathrm{K}$-source, $\mathrm{K}$-feldspar is one of the most important $\mathrm{K}$ minerals (Straaten, 2002). Several laboratory studies have shown that microbes can increase the 


\section{Abo El-Khair, Amal W. et al.}

dissolution rate of silicate and aluminum silicate minerals in laboratory patches experiments, primarily by generating organic and inorganic acids (Barker et al., 1997). Microbes can enhance mineral dissolution rate by producing and excreting metabolic by-products that interact with the mineral surface. Complete microbial respiration and degradation of particulate and dissolved organic carbon can elevate carbonic acid concentration at mineral surfaces, in soils and in ground water (Paris et al., 1996), which can lead to an increase in the rates of mineral weathering by a proton-promoted dissolution mechanism. In addition to carbonic acid, microbes can produce and excrete organic ligands by a variety of processes such as fermentation and degradation of organic macromolecules, or as a response to nutrient stress (Berthelin, 1983 and Paris et al., 1996). It is well known that many organic compounds produced by microorganisms, such as acetate, citrate and oxalate can increase mineral dissolution rate (Welch and Ullman, 1993). Carboxylic acid groups which shown to promote dissolution of silicates are also common in extra cellular organic materials. Moreover, some microorganisms in soil environment contain enzymes that function in ways analogous to chitinase and celluloses, i.e., they specifically break down mineral structure and extract elements required for metabolism or structure purposes (e.g., mineralizes) (Barker et al., 1987). In the present study, using the dual inoculation of both $B$. circulans and cyanobacteria gave the highest potato tuber yield when both combined with the chemical source of potassium $\left(\mathrm{K}_{2} \mathrm{SO}_{4}\right)$ applied at $1 / 2$ and full $\mathrm{K}$ levels compared feldspar $\mathrm{K}$ source. This result can be explained by that cyanobacteria are known to excrete extracellularly a number of compounds like polysaccharides, peptides, lipids....etc. during their growth in soil, which increased the number of bacteria in soil and in turn increased the number of potassium dissolving microorganisms that help in releasing the soluble into soil (Mandal et al., 1999). It is also known that the natural form of potassium such as feldspar is a slow release material over a period time. However, natural materials are broken down by soil microorganisms which are very sensitive for the environmental conditions (Ali, et al., 2007). In addition, cyanobacteria rather than they can fix the atmospheric nitrogen; they have the ability to dissolve non-soluble phosphate in soil and add to soil fertility (Hedge et al., 1999). Ali and Taalab (2008) studied the response of onion productivity to the application of potassium at different forms and rates. Results showed that the highest plant vegetation growth character (the tallest plant, the highest leaves number, the heaviest fresh, dry weight of whole plant, total bulbs yield per unit area and dimension of bulb as well as its average weight) were detected with using chemical form of $\mathrm{K}$ as potassium sulfate. The poorest vegetative plant growth characters were detected when used feldspar as source of natural potassium. They also added that inoculation with silicate bacteria helped increasing the amount of available potassium in soil and consequently improved onion vegetative characters and bulb yield. Such results are similar to those recoded in the present study with potato. Average potato tuber weight, tuber yield, potato tuber carbohydrate and soluble sugar contents had increased due to the inoculation with both $B$. circulans and cyanobacteria each singly or both in dual application in combination with both potassium 
sources. This effect might be due to that applying biofertilizer increased microorganisms in the soil, which convert the ability of mobilizing the unavailable forms of nutrient elements to available form. Also the microorganisms produce growth promoting substances, which increase plant growth. This increase in plant growth may increase the photosynthetic rates leading to an increase of the assimilation rates. So that the tuber weight and tuber size increased, this consequently increased the total tuber yield (AbouHussein et al., 2002).

In conclusion, $\mathrm{K}$ deficiencies become problem especially in crops require large quantities because $\mathrm{K}$ decreases easily in soils due to crop uptake, runoff, leaching and soil erosion, So the use of bio fertilizers should be frequently applied to compensate the loss of potassium through these processes and ensure maintaining the soil fertility. In addition, the use of potassium (K-rock) minerals may be agronomically more useful and environmentally more feasible than soluble K. However, more studies and field trials should be run in the near future to reach the levels of recommendation.

\section{REFERENCES}

Abdel-Wahab, A. F.M; A. M. Biomy and W. M. El-Farghal (2003). Effect of some natural soil amendments on biological nitrogen fixation, growth and green yield of pea plant grown on sandy soil. Fayoum J. Agric. Res. and Develop., 17: 47-54.

A. O. A. C. (1990). Association of Official Analytical Chemists, Official Methods of Analysis, 15 ${ }^{\text {th }}$ (Ed.), (Horwitz, W., Ed.), Washington, DC., USA.

Abou-Arab, A. A; S. M. Mohamed M. A. Mohamed and A. M. Ibrahim (1998). Plant productivity, nutrient status and uptake as influenced by soil compaction and water stresses. Egypt. J. Soil Sci., 38(1-4), 229.

Abou Hussein, S. D., I. El- Oksh, T. El- Shorbagy and A. M. Gomaa (2002). Effect of cattle manure, biofertilizers and reducing mineral fertilizer on nutrient content and yield of potato plant. Egypt. J. Hort., 29(1): 99 115.

Ali Aisha, H., A. Fatma, Rizk, A.M. Shaheen and Mona, M. Abdel-Mouty (2007). Onion plant growth, bulbs yield and its physical and chemical properties as affected by organic and Natural fertilization. Res. J. Agric. \& Biol. Sci., 3(5): 380-388.

Ali Aisha, H., A. and A. S. Taalab (2008). Effect of natural and/or chemical potassium fertilizers on groweh, bu;bs yield and some physical and chemical costituents of onion (Allium cepa L.). Res. J. Agric. And Biol. Sci., 4(3): 228237.

Allen, O. M. (1959). Experements in soil bacteriology. 1st Ed. Burgess Publishing Co., Minneapolis, Minnesota.

Allen, M. M. and R. Y. Stanier (1968): Selective isolation of blue-green algae from water and soil. J. Gen. Microbiol., 51: 203 - 209. 
Barker, W. W., S. A. Welch and J. F. Banfield (1997). Geomicrobiology of silicate minerals weathering. Rev. Mineral, 35: 391-428.

Barker, W.W., S. A. Welch, S. Chu and F. Banfield, F. H. Chapelle, J. L. Zelibor, D.Y. Grimes and L. L. Knobel, (1987). Bacteria in deep coastal plain sediments of Maryland: A possible source of $\mathrm{CO}_{2}$ to groundwater. Water Resources Res., 23: 1625-1632.

Berthelin, J. (1983). Microbial weathering processes. In Microbial Geochemistry (ed. W.E. Krumbein), 223-262. Blackwell Scientific Publications.

Casida, L . E., Klein, D. A. and Santoro, T. (1964). Soil dehyderogenase activity. Soil Sci. 98: 371-376.

Chapman, H. D. and P. F. Pratt (1961). Methods of Analysis for Soils, Plants and Water. Agric. Publ. Univ., of California, Riverside, USA.

Cochran, W. G. (1950). Estimation of bacterial densities by means of the Most Probable Number. Biometrics, 6: 105-116.

Conacher, J. and A. Conacher (1998). Organic farming and the environment with particular reference to Australia. A review. Biological Agriculture and Horticulture.16: 145-171.

Difico Manual (1984). Dehydrated Culture Media and Reagents for Microbiology. $10^{\text {th }}$ Edition. Difco Laboratories, Detroit, Michigan, USA.

Dubbois; M.; K. A.; J. K. Hamilton, P. A. Rebers and F. Smith (1956). Colorimetric method for determination of sugars and related substances. Anal. Chem., 28: $350-356$.

EL-Hddad, M. E., Y. Z. Ishac and M. I. Mostafa (1993). The role of biofertilizers in reducing agricultural costs, decreasing environmental pollution and raising the crop yield. Arab Univ. J. Agric. Sci., Ain Shams Univ., 1(1): 147-160.

Ghazal, F. M. A. (1987). Microbial studies on nitrogen fixation by alga and Azolla. Ph.D. Thesis, Fac. of Agric. Al-Azhar University, Cairo, Egypt.

Gomez, K. A. and A. Arturo, Gomez (1984). Statistical procedures for Agricultural research, (2 ${ }^{\text {nd }}$ ed), pp. 20-29 \& 359-387.

Hedge, D. M., B. S. Dwivedi and S. N. Sudhakara (1999). Biofertilizers for cereal production in India- A Review. Ind. J. Agric Sci., 69(2): 73 - 83.

Jensen, E. S. and H. Hauggaard (2003). How can increased use of biological $\mathrm{N}_{2}$-fixation in agriculture benefit the environment ?. Plant and Soil. 252: 177-186.

Kloepper, J. W.; D. J. Hume; F. M. Scher; C. Singieton; B. Tipping; M. Laliberte; K. Frauley; T. Kutchaw; C. Simonson; R. Lifshitz, I. Zaleska and L. Lee (1988). Growth-promoting rhizobacteria on canola (rape seed). Plant Dis., 72: 42-46.

Mandal, B. K., Velk, P. L. G. and Mandal, L. N. (1999). Beneficial effects of blue-green algae and Azolla, excluding supplying nitrogen, on wetland rice fields: a review. Biol. Fertl. Soils, 28: 329-342.

Marschner, H. (1995). Mineral nutrition of higher plants. Academic Pess, London, pp: 889. 
Mekhemar, G.A.A; F.M. Ismail; F.Sh.F. Badawi and B.A.A. Kandil (2007). Response of Peanut (Arachis hypogaea L.) to co-inoculation with Bradyrhizobium spp. and phosphate dissolving bacteria under different levels of phosphorus fertilization in sandy soils. Agric. Res. J., Suez Canal Univ., 7 (1): :1-8.

Page, A. L.; R. H. Miller and D. R. Keeney (1982). "Methods of Chemical Analysis". Part 2: Chemical and microbiological properties (Second Edition). American Society of Agronomy, Inc. and Sci. Soc. of America, Inc. Publishers, Madison, Wisconsin, USA.

Paris, F., B. Botton and F. Lapeyrie (1996). In vitro weathering of phlogopite by ectomycorrhizal fungi. Plant and soil.179: 141-150.

Rippika, R.; J. Deruelles; J. B. Waterbury; M Herdman, and R. Y. Stanier. (1979). Generic assignments, strain histories and properties of pure cultures of cyanobacteria J. Gen. Microbiol., 111: $1-61$.

Ruggiero, C.; S.D. Pascale and M. Fagnano (1999). Plant and soil resistance to water flow in faba bean Vicia faba L. major Harz. Plant and Soil. 210, 291.

Shields Lora, M. and L. W. Durrell (1964). Algae in relation to soil fertility. Newphytol., 30: $92-128$.

Straaten, P.V. (2002). Rocks for crops, ICRAF. Narobi, Kenya, pp: 338.

Steudle, E. (1994). Water transport across roots. Plant and Soil. 167:79.

Steudle, E. and A. Peterson (1998). How does water get through roots?. J. Exper. Bot; 49:775.

Thajuddin, N. and G. Subramanian (2005). Cyanobacterial biodiversity and potential application in biotechnology. Current Sci., 89(1): $47-57$.

Welch, S. A. and W. J. Ullman (1993). The effect of organic acid on plagioclase dissolution rates and stoichiometry. Geochim. Cosmochim. Acta. 57: 2725-2736.

Zahara, M.K. (1969). Studies on Silicate Bacteria. M.Sc. Thesis, Fac. Agric., Cairo Univ., Egypt. 


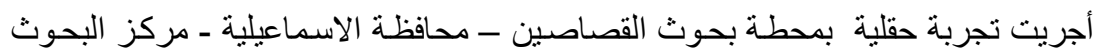

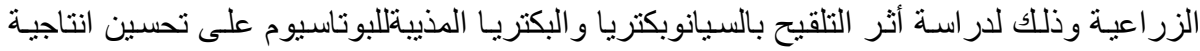

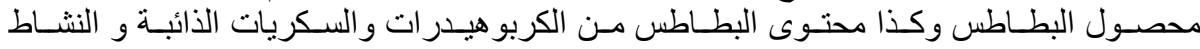

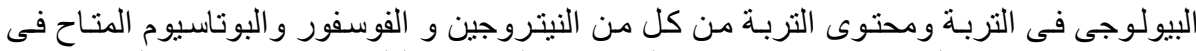

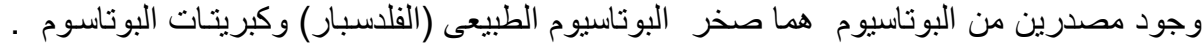

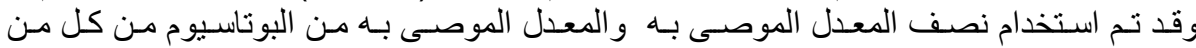

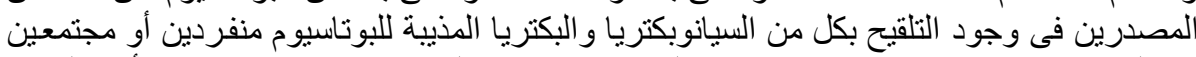

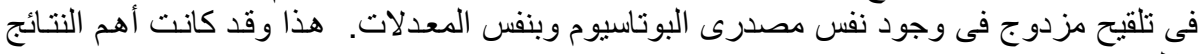

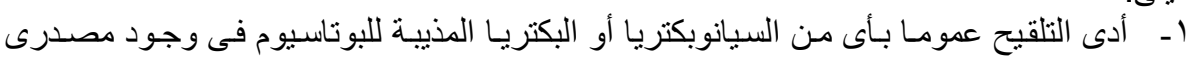

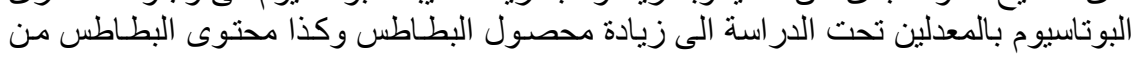

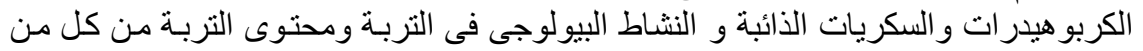

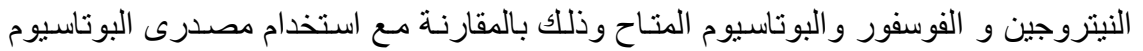
منفردين.

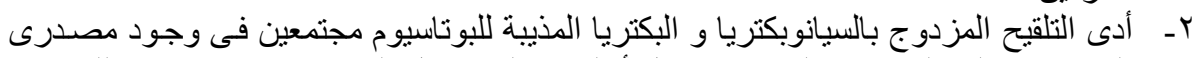

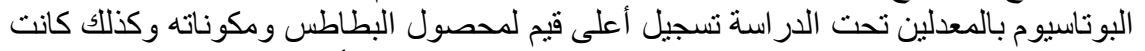

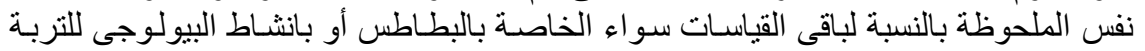

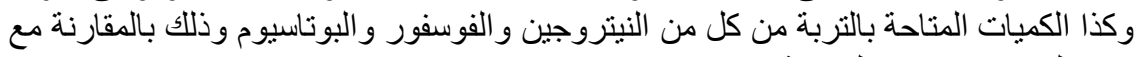

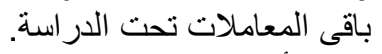

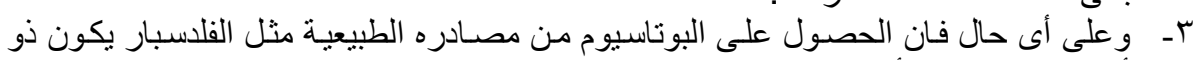

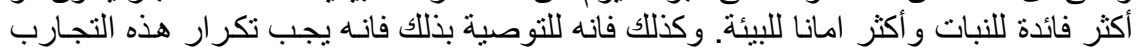
فى المستقبل ومع محاصيل أخرى حتى نستطيع الوصول النئ الى مسنوى التوصية. 
J. Agric. Sci. Mansoura Univ., 34 (5): 4315 - 4328, 2009

Table (4): Soil biological activity and microbial count at different period as affected with different potassium sources and levels and inoculation with silicate bacteria and/or cyanobacteria

\begin{tabular}{|c|c|c|c|c|c|c|c|c|c|c|c|c|c|c|}
\hline \multirow[t]{2}{*}{ Treatment } & \multirow[t]{2}{*}{ K - level } & \multirow{2}{*}{$\begin{array}{l}\text { Inoculation } \\
\text { type }\end{array}$} & \multicolumn{2}{|c|}{$\begin{array}{c}\text { DHA } A^{\star \star *}(\mu \mathrm{g} \text { TPF } \\
\mathrm{g}^{-1} \text { dry soil) }\end{array}$} & \multicolumn{2}{|c|}{$\begin{array}{c}\mathrm{CO}_{2} \text { evolution mg } \\
\mathrm{CO}_{2} 100 \mathrm{~g}^{2} \text { soil }^{-1} \\
\text { day }^{-1}\end{array}$} & \multicolumn{2}{|c|}{$\begin{array}{c}\text { Cyano. Count } \\
\times 10^{3} \mathrm{cfu}^{\star \star \star} \mathrm{g} \\
\text { soil }^{-1}\end{array}$} & \multicolumn{2}{|c|}{$\begin{array}{l}\text { Bacteria. } \\
\text { Count } \times 10^{7} \\
\text { cfu g soil }{ }^{-1}\end{array}$} & \multicolumn{2}{|c|}{$\begin{array}{l}\text { Azotobacter } \\
\text { Count } \times 10^{4} \\
\text { cfu g soil }{ }^{-1}\end{array}$} & \multicolumn{2}{|c|}{$\begin{array}{l}\text { Azospirillum } \\
\text { Count x } 10^{4} \\
\text { cfu g soil }^{-1}\end{array}$} \\
\hline & & & $\begin{array}{c}75 \\
\text { days }\end{array}$ & $\begin{array}{c}95 \\
\text { days }\end{array}$ & $\begin{array}{l}75 \\
\text { days }\end{array}$ & $\begin{array}{c}95 \\
\text { days }\end{array}$ & $\begin{array}{c}75 \\
\text { days }\end{array}$ & $\begin{array}{c}95 \\
\text { days }\end{array}$ & $\begin{array}{c}75 \\
\text { days }\end{array}$ & $\begin{array}{c}95 \\
\text { days }\end{array}$ & $\begin{array}{c}75 \\
\text { days }\end{array}$ & $\begin{array}{l}95 \\
\text { days }\end{array}$ & $\begin{array}{l}75 \\
\text { days }\end{array}$ & $\begin{array}{c}95 \\
\text { days }\end{array}$ \\
\hline \multirow{4}{*}{$\begin{array}{l}\text { Potassium } \\
\text { sulfate }\end{array}$} & \multirow{2}{*}{ 1/ 2 Full K dose } & Bacte & 27.74 & 17.41 & 99.83 & 90.34 & 10 & 7 & 15 & 12 & 10.2 & 2.17 & 9.20 & 2.20 \\
\hline & & Cy & 23.23 & 15.28 & 86.76 & 74 & 13 & 8 & 13 & 11 & 9.2 & 1.26 & 6.80 & 0.06 \\
\hline & \multirow{2}{*}{ Full K dose } & & 30 & & 146 & & $\sqrt{2}$ & 6 & 15 & 14 & 11.2 & 20 & 10 & 2.20 \\
\hline & & & 28. & & & & & 10 & $1 t$ & 12 & 11 & 2. & 0 & 1.49 \\
\hline \multirow{4}{*}{ Feldspar } & \multirow{2}{*}{ 1/ 2 Full $K$ dose } & Bacteria & 24.44 & 15.26 & 98.66 & 73.14 & 6 & 4 & 11 & 9 & 7.4 & 1.12 & 2.80 & 0.37 \\
\hline & & & 20.39 & & & & 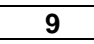 & 5 & 12 & 10 & 9.8 & 1.12 & 1.40 & 0.00 \\
\hline & \multirow{2}{*}{ Full $\mathrm{K}$ dose } & $\mathrm{Bac}$ & 29.46 & 17.69 & 120 & 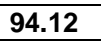 & 12 & - & 13 & 10 & 9 . & 8 & 1. & 0.02 \\
\hline & & & 25.09 & 15.66 & 99 & & & & 14 & 11 & 8.2 & 1. & 1.8 & 0.09 \\
\hline \multirow{2}{*}{$\begin{array}{l}\text { Potassium } \\
\text { sulfate }\end{array}$} & \multirow{2}{*}{\begin{tabular}{|c|} 
1/ 2 Full K dose \\
Full K dose
\end{tabular}} & \multirow{4}{*}{$\begin{array}{c}\text { Bacteria } \\
+ \\
\text { Cyano. }\end{array}$} & 30.10 & 18.95 & 122.15 & 95.3 & 1 & 11 & 19 & 14 & 12.2 & 2. & 10. & 2.32 \\
\hline & & & 40.65 & 26.22 & & & & 1 & 2 & 16 & 13 & 4. & 12 & 3.42 \\
\hline \multirow{2}{*}{ Feldspar } & \multirow{2}{*}{\begin{tabular}{|c} 
1/ 2 Full K dose \\
Full K dose \\
\end{tabular}} & & 26. & & & & & 1( & 14 & 10 & 10 & & 9. & 1.51 \\
\hline & & & 32.16 & 19.00 & 135.65 & 95.32 & 15 & 10 & 16 & 11 & 11.70 & 2.10 & 11.01 & 2.75 \\
\hline \multirow{2}{*}{$\begin{array}{c}\text { Potassium } \\
\text { sulfate }\end{array}$} & \multirow{2}{*}{\begin{tabular}{|c|} 
1/ 2 Full K dose \\
Full K dose \\
\end{tabular}} & \multirow{4}{*}{$\begin{array}{l}\text { Without } \\
\text { inoculation }\end{array}$} & 15.78 & 14.23 & 47.01 & 35.0 & & 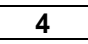 & 5 & 3 & 16 & $0 . \varepsilon$ & 1.20 & 0.10 \\
\hline & & & 18.14 & 15.66 & 68.98 & 49. & & & & 5 & $\pi$ & 0 & 3.1 & 0.092 \\
\hline \multirow{2}{*}{ Feldspar } & \multirow{2}{*}{\begin{tabular}{|c|} 
1/ 2 Full K dose \\
Full K dose \\
\end{tabular}} & & 14. & & & & 3 & 4 & 4 & 5 & & & 2. & 0.17 \\
\hline & & & 15.16 & 12.61 & 40.66 & 34.72 & 3 & 4 & 5 & 3 & 9.2 & 0.17 & 2.84 & 0.46 \\
\hline
\end{tabular}

${ }^{*}$ Silicate bacteria ${ }^{* \star}$ Cyanobacteria ${ }^{* \star *}$ DHA $=$ Dehydrogenase activity ${ }^{\star \star \star}$ cfu $=$ colony formed unit ${ }^{-1}$. 